\title{
Examination of Social Media Attitudes and Loneliness Levels of Secondary Education Students with Regard to Gender and Sport
}

\author{
Gaye Erkmen ${ }^{1} \&$ Mehmet Altın ${ }^{1}$ \\ ${ }^{1}$ Selçuk University, Sport Sciences Faculty, Recreation Department, Konya, Turkey \\ Correspondence: Gaye Erkmen, Selçuk University, Sport Sciences Faculty, Recreation Department, Konya, Turkey.
}

Received: September 4, 2018

Accepted: September 20, 2018

Online Published: September 26, 2018

doi:10.5430/ijhe.v7n5p54

URL: https://doi.org/10.5430/ijhe.v7n5p54

\begin{abstract}
The purpose of the study was to examine secondary school students' attitudes towards social media and their loneliness levels in terms of gender and whether they do sports or not. The sample of the study consisted of 175 female and 269 male secondary school stıdents. To collect data personal information form, Social Media Attitude Scale (Otrar ve Argin, 2013) and UCLA Loneliness Scale (Russell, Peplau, \& Cutrona, 1980) were used to in this study. Independent $t$ test analysis was conducted to examine whether the participants' social media attitudes and loneliness levels differed with regard to gender and do sport. According to the results, there was no significant difference in social media attitudes $(t=-.832, \mathrm{p}>.05)$ with regard to gender. However, loneliness levels of the participants seems to be significantly different with regard to gender $(t=-6.513, p=.000)$. When the participants were examined whether they do sports or not, there was not any significant difference in social media attitudes $(t=$ -.427, $\mathrm{p}>.05$ ). However, the levels of loneliness was significantly found to be different in terms of doing sports or not $(t=-3.675, p=.000)$. Furthermore, there was not a significant relationship between social media attitudes and loneliness $(\mathrm{p}>.05)$. It can be concluded that sport and regular physical activity can be considered as a means to provide environments where individuals will feel far away from the feeling of loneliness and that they will feel themselves more valuable.
\end{abstract}

Keywords: social media attitudes, loneliness, gender, sport

\section{Introduction}

As the internet has become an indispensable part of our lives in several areas, it is being used prevalently for different purposes such as information, communication and entertainment. Social media are computer-assisted technologies that make it easier to create and share individuals' information, ideas, career interests and other forms of expression by the means of virtual communities and networks (Kietzmann, Hermkens, McCarthy, \& Silvestre, 2011). Kaplan and Haenlein (2010) described social media as the entirety of internet-based applications that allow user-centered production and development of ideological and technological contents and constructs over Web 2.0. Social networks have allowed us to restructure social environments in a different way and have begun to take up a larger space in our lives. People have become used to sharing their daily lives, experiences and areas of interest with their families, friends and acquaintances in order to communicate (Morahan-Martin and Schumacher 2003).

In the report by the digital marketing agency WeAreSocial and Hootsuite (2018), it was seen that the highest rate of using social media was in the age group of $16-64$ by $64 \%$. How important the influence of social media may be can be reflected by the fact that $34 \%$ of the user profile of Facebook, which is the first choice of social media users, are in the age group of 18-34. Almost $93 \%$ of youths in the age group of 12-17 used various social network sites in a considerable part of their day (Lauricella, Cingel, Blackwell, Wartella, \& Conway, 2014). Huston and Ripke (2006) reported that youths in the age group of 8-17 mostly used social networks as a method to communicate with their peers. One may encounter several studies which reported that the ratio of young population on social media is higher (Usluel \& Mazman, 2009; Vural \& Bat, 2010; Akyazı \& Tutgun Ünal, 2013; Lauricella et al., 2014; Huston \& Ripke, 2006).

It is seen that the technologies that are used for purposes of information, communication and entertainment today provide individuals advantages in several different areas. With the help of social networks, it has now become much easier for people to communicate with other people without face-to-face interaction and join different groups (Leung, 2002; Pempek, Yermolayeva, \& Calvert, 2009). Studies have shown that individuals reach a sort of social support 
through social media to reduce their feelings of loneliness (Martončik \& Lokša, 2015; Morahan-Martin \& Schumacher, 2003; Ryan \& Xenos, 2011).

While starting to use the internet extensively makes our lives easier, studies on the effects of misusing of it have been increasing in numbers (Ceyhan 2011). When this issue is not put into the right perspective, aside from the internet and social media applications making our lives easier and increasing our quality of life, these may emerge as a powerful addiction in individuals that is difficult to overcome. While this causes different behaviors and affection in different individuals, the literature reported that it causes feelings of loneliness and negative affectivity in cases of uncontrollable usage (Kelleci, 2008; Kraut et al., 1998; Moody, 2001; Sanders, Field, Diego, \& Kaplan, 2000; Jung, 2012). Do individuals' interests in social media make them lonely, or, are individuals who are lonely trying to solve their socializing problems via social media? Whatever the answer may be, in both cases we are confronted with the fact that we are not able to use social media properly. Especially young people spend so much time on social media without realizing it that, this may be seen as a case of social isolation. Greenwood (2008) described two types of isolation as passive and active isolation. While passive isolation is defined as pulling oneself from environment due to reasons such as anxiety, shyness and excessive sensitivity in social relationships, active isolation is defined as the exclusion of the individual from the group by the members due to the failure of the individual in performing the responsibilities of the group. Particularly, recent studies have reported significant relationships between internet usage and loneliness (Morahan-Martin \& Schumacher, 2000; Sanders et al., 2000; Whang, Lee, \& Chang, 2003). Çağır and Gürgan (2010) emphasized that problematic internet usage is increasingly spreading among university and high school students, and it has a medium-level positive relationship with loneliness. Therefore, this study will investigate the loneliness levels and social media attitudes of high school students based on different variables.

Loneliness is defined as an unpleasant feeling that experienced when the individual realizes the difference between the existing social relationship and the social relationship they would like (Peplau \& Perlman, 1982). Moreover, it is considered to have harmful effects on a set of characteristics of emotional or psychological well-being (Heinrich \& Gullone, 2006). Lou (2009) reported that individuals who experience feelings of loneliness have negative affectivities, they have problems in trusting themselves and their environment, find it difficult to concentrate on success and experience communication and interaction problems with their environment. Lonely individuals have pessimistic expectations in their social relationships, they cannot form long-term friendships with others and they lack basic social skills (Beal, 2006). Studies have reported that, with the increase in the time spent on the internet and social media networks by students, it is seen that alienation from social life and isolation emerge in individuals (Otrar \& Argin, 2014).

It should be known that, if internet and social media usage is planned without considering its both positive effects and educational requirements, it has the power and effect to destroy the social structure and the cultural texture. When we consider social media addiction, we cannot find enough cultivated methods about how to avoid the excessive usege of social media. It is thought that social media attitude and habit education and individuals' sport culture earnings will prevent addiction, negative affect and problematic behaviors. While there are many studies about social media usage and loneliness conducted with high school students, there are no comparative studies about social media attitudes, frequency of social media use, social media dependency levels of athletes and non-athletes. Some studies have examined issues related to social media attitudes and beliefs of college athletes (Boissonneault, 2015), social media effects on athletes (Frisby, 2010), social media, fanship and athletes behaviors (Wirth, 2014). It is thought that revealing the difference between the social media attitudes and the loneliness levels of the individuals who do and do not sports will give a light to the studies will be done in different dimensions and scope.

Considering these effects of social media that surround our lives, the purpose of the present study was to investigate the social media attitudes and loneliness levels of high school students in terms of their gender and status of participating in sports.

\section{Method}

\subsection{Design and Sample}

The sample of the study was determined by convenience sampling method which is one of the non-random sampling methods. The sample consisted of total of 444 high school students including 175 female $\left(M_{\text {age }}=15.46 \pm .95\right)$ and 269 male $\left(M_{\text {age }}=15.41 \pm .97\right)$ students. While 230 of the participants took part in sports in different branches, 214 did not. Based on the participants' statements, they used social media by the mean time of 2 hours $( \pm .48)$ per day, and 389 of the participants stated that they had social media accounts. 


\subsection{Data Collection Tools}

Personal Information Form: This form was prepared by researchers to collect information on the participants' age, gender, status of participating in sports, social media membership, and reasons for using social media.

Social Media Attitudes Scale: The scale, which was developed by Otrar and Argin (2013) to determine the attitudes of students towards social media, consists of 23 items including 17 positive and 6 negative items and 4 factors (need for sharing, social capacity, social isolation and relationship with teachers). It is scored as a 5-point Likert-type scale based on responses ranging from "completely agree" to "completely disagree". In the analyses of internal consistency in this study, the Cronbach's Alpha value was found as .81.

UCLA Loneliness Scale: The scale developed by Russell, Peplau and Cutrona (1980) consists of a total of 20 items including 10 directly scored and 10 reversely scored items. All items are scored from 1 to 4 . While calculating the loneliness score, the reversed items' scores are reversed. The possible range of scores in the scale is from 20 to 80 . Higher scores indicate higher levels of loneliness, while lower scores indicate lower levels of loneliness. The validity and reliability of the scale were tested for the Turkish language by Demir (1989). The Cronbach's Alpha value in this study was found as .90 .

\subsection{Data Collection}

The permissions required for data collection were obtained, and the data were collected by the researcher. Before distributing the form that contained the measurement instruments to the participants, the participants were informed about the study, and their voluntary participation was achieved. Filling out the form took approximately 10 minutes.

\subsection{Data Analysis}

In this study, firstly preliminary analyses (assumption checking, descriptive statistics) were carried out, and then, independent-samples t-test was used to reveal whether or not there were significant differences in the social media attitudes and loneliness levels of the participants based on their gender and status of participating in sports. Additionally, the Pearson product-moment correlation coefficient was examined to test whether or not there was a relationship between the social media attitudes of the participants and their levels of loneliness. To be able to test the assumptions of the independent-samples t-test, normal distribution, extreme values and homogeneity of variance were examined. All analyses were carried out by using the IBM SPSS Statistics 22.0 software.

\section{Results}

One of the assumptions of the analysis in the study, the normal distribution assumption, was satisfied for the sample (Shapiro-Wilk $\mathrm{p}>.05$ ). The $\mathrm{z}$ values were examined to determine the extreme values, and three extreme values were removed from the data set. After the removed data, the sample consisted of 444 participants. The significance of Levene's coefficients were examined to understand whether or not the variance between the groups was homogenous, and it was observed that the variances between the gender groups were not homogenous (Levene's $p<.05$ ), while the variances in the groups based on participation in sports were homogenous (Levene's $p>.05$ ).

According to the analysis results, there was no significant difference between the social media attitudes of the participants with regard to gender $(t=-.832, \mathrm{p}>.05)$. However, the loneliness levels of the participants differed significantly with regard to gender $(t=-6.513, \mathrm{p}=.000)$. Table 1 shows that the mean loneliness level of the female students was higher than that of the male students.

Table 1. Independent-Samples t-Test Results on Social Media Attitudes and Loneliness Levels with regard to Gender

\begin{tabular}{|c|c|c|c|c|c|c|}
\hline Variables & Group & $n$ & $M$ & $S D$ & $t$ & $p$ \\
\hline \multirow{2}{*}{ Social Media Attitude } & Female & 269 & 50.22 & 4.62 & \multirow{2}{*}{-.832} & \multirow{2}{*}{.406} \\
\hline & Male & 175 & 49.83 & 5.36 & & \\
\hline \multirow{2}{*}{ Loneliness } & Female & 269 & 56.01 & 4.55 & \multirow{2}{*}{$-.6 .513$} & \multirow{2}{*}{$.000^{*}$} \\
\hline & Male & 175 & 52.79 & 5.83 & & \\
\hline
\end{tabular}

p $<.001$

While there was no significant difference in the social media attitudes of the participants with regard to participating in sport or not $(\mathrm{t}=-.427, \mathrm{p}>.05)$, the difference in the loneliness levels was significant in terms of this variable $(\mathrm{t}=$ $-3.675, p=.000)$. Table 2 shows that the mean loneliness level of the participants who took part in sports was lower than those who did not. 
Table 2. Independent-Samples t-Test Results on Social Media Attitudes and Loneliness Levels with regard to Participating Sport or not

\begin{tabular}{lllllll}
\hline Variables & Group & $n$ & $M$ & $S D$ & $t$ & $p$ \\
\hline \multirow{2}{*}{ Social Media Attitude } & Do sport & 230 & 49.88 & 4.95 & \multirow{2}{*}{..427 } & \multirow{2}{*}{.669} \\
& Do not sport & 214 & 50.09 & 5.22 & & \\
Loneliness & Do sport & 230 & 53.13 & 5.39 & & \multirow{2}{*}{.365} \\
& Do not sport & 214 & 55.06 & 5.62 & & \\
\hline
\end{tabular}

${ }^{*} \mathrm{p}<.001$

The Pearson product-moments correlation coefficient was examined to determine whether or not there was a relationship between the social media attitudes and loneliness levels of the participants, and there was not found a significant relationship $(\mathrm{r}=-.004, \mathrm{p}=.934)$.

\section{Discussion}

The purpose of the study was to investigate the social media attitudes and loneliness levels of high school students based on their gender and status of participating in sports, the participants showed similar social media attitudes regardless of gender. In addition to this, it was found that the female students had higher loneliness levels than those of the male students, and the students who did not participate in sports had higher loneliness levels than those who did.

There was no statistically significant difference between female and male participants Social Media Attitudes Scale's mean scores. Studies also found that there was no significant difference in the social media attitude scores based on the variable of gender (Ökte, 2012; Özsarı \& Karaduman, 2016).

Studies that revealed that there was no significant difference in loneliness levels based on gender (illhan, 2012). While some studies showed that women had higher levels of loneliness in comparison to men (Schultz \& Moore, 1986), there are also studies which demonstrated that men had higher levels of loneliness in comparison to women (Cramer \& Neyedley, 1998; Özgür, 2013; Atli, Keldal, \& Sonar, 2015). The mean loneliness level of the female students was significantly higher than that of the male students. It can be said that present study is parallel to the literature.

Sport is regarded as a socially acceptable way of expelling repressed feelings, and in order to remove oneself from the monotony or oppression of everyday life (Woods, 2011). Even if young people do not play sports, it is seen that they are actively and enthusiastically following their favorite team or athletes from social media. Therefore, it can be said that social media has recently been seen as a popular place for young people's self-expressions and a common choice for interpersonal communication without taking into account they participate in sport or not. The time that is spent on social media by young people who participate in sports is naturally shorter, and considering that they are thus able to understand the meaning of the value of socializing and real sharing more, it was proposed that social media attitudes may differ between those who participate in sports and those who do not. However, the results here did not show any significant difference in the attitudes of the participants towards social media based on whether they participated in sports or not. This result in our study may be explained by the structure of the sample, prevalence of social media, social differences and differences based on the sports culture.

The students who did not participate in sport had significantly higher levels of loneliness in comparison to those who did. Studies have shown that physical activity and sports, which lead to several positive psychological outcomes, also have an inverse relationship with loneliness (Haugen, Säfvenbom \& Ommundsen, 2013; Page, Frey, Talbert, \& Falk, 1992; Page \& Page 1994; Page \& Zarco 2001; Poulsen, Ziviani, Johnson, \& Cuskelly, 2008). As sports activities strengthen bonds and provide opportunities of good peer relationships and friendship, they may be seen as a supporting element in developing a sense of social self (Harter, 1999) and reducing feelings of loneliness (Page et al., 1992). Therefore, this finding of our study was in direct agreement with the literature.

Our study did not find a significant relationship between the social media attitudes and loneliness levels of the participants. Özsarı and Karaduman (2016) also did not find a significant relationship between the social media attitudes and loneliness levels of faculty of education students. Another study observed that loneliness in social relationships did not predict usage of social networks (Doğan \& Karakuş, 2016). However, Tiryaki (2018) study indicated that there was a significant positive relationship between feelings of loneliness and social media using motivations. Bonetti and colleagues (2010) have found that there was a positive correla-tions between loneliness and 
social media usage. The feeling of loneliness increases, motivation for using social media is also increases in male and females. Considering the studies that revealed that social media usage leads to isolation of individuals and others that showed in contrast that individuals who feel lonely are more active on social media, we believe that these differences in results may have been caused by this bidirectional relationship.

We should state that our study had some limitations. Firstly, due to its cross-sectional design, no conclusions can be drawn regarding causality. Secondly, as our sample was determined by convenience sampling which power of representing the population is quitely low. As the students in our sample were selected from different class levels, this study did not take into account that the social media attitudes of the students who were preparing for the university entrance examination might be different. It is needed to consider that there may be a difference in the frequency and time of usage of social media by students in their preparation year, and future studies may assess this variable. Another issue that may be considered to be a limitation was that the means of the students for using social media was not investigated. It is believed that determining the devices students have and may utilize for using social media such as computers, smartphones and tablets may provide advantages in explaining their social media attitudes and usage. It is thought that making a comparison in future studies by determining individuals' reasons of social meadia using and their levels of loneliness may provide a better explanation of the relationship between social media attitudes and loneliness levels.

With this study, it might be stated that the high school students showed similar social media attitudes regardless of their gender. In addition to this, it may be seen that the loneliness levels were higher among the female students in comparison to the male students and among those who did not participate in sports in comparison to those who did. It can be concluded that sport participation during adolescence may include important social components to help adolescents' social needs and expectations which in turn may prevent negative feelings such as loneliness. It is thought that it would be important to expand the use of social media as an educational material in order to ensure effective participation of sports and regular exercise behavior. Therefore, for the educational use of social media, the younger generation should be encouraged.

\section{References}

Akyazı, E. \& Tutgun-Ünal, A. (2013). İletişim fakültesi öğrencilerinin amaç, benimseme, yalnızlık düzeyi ilişkisi bağlamında sosyal ağları kullanımı [Purpose, adoption and level of loneliness relation and the use of social networks: A study on undergraduate communication students]. Global Media Journal Turkish Edition, ISSN: 1309-7601, 3(6), 1-24.

Atli, A., Keldal, G., \& Sonar, O. (2015). Üniversite öğrencilerinin yabancılaşma ile yalnızlık düzeyleri arasındaki ilişki. Mustafa Kemal Üniversitesi Sosyal Bilimler Enstitüsü Dergisi, 12(29).

Beal, C. (2006). Loneliness In Older women: A Review Of The Literature. Issues in Mental Health Nursing, 27, 795-813. https://doi.org/10.1080/01612840600781196

Boissonneault, E. (2015). Student-Athletes' Attitudes and Beliefs Towards Social Media, Graduate Theses. http://digitalcommons.winthrop.edu/graduatetheses.

Bonetti, L., Campbell, M. A., \& Gilmore, L. (2010). The relation-ship of loneliness and social anxiety with children's and adolescents' online communication. Cyberpsychology, Behavior, and Social Networking, 13(3), 279-285. https://doi.org/10.1089/cyber.2009.0215

Ceyhan, A. A. (2011). University students' problematic Internet use and communication skills according to the internet use purposes. Theory and Practice, 11(1), 69-77. https://files.eric.ed.gov/fulltext/EJ919890.pdf

Cramer, K. M., \& Neyedley, K. A. (1998). Sex differences in loneliness: The role of masculinity and feminity. Sex Roles, 38, 645-653. https://doi.org/10.1023/A:1018850711372

Çağır, G. \& Gürgan, U. (2010). Lise ve Üniversite Öğrencilerinin Problemli İnternet Kullanım Düzeyleri İle Algılanan İyilik Halleri ve Yalnızlık Düzeyleri Arasındaki İlişki, Balıkesir Üniversitesi Sosyal Bilimler Enstitüsü Dergisi, 13(24), s. 70-85.

Demir, A. (1989). UCLA Yalnızlık Ölçeğinin geçerlik ve güvenirliği. Turk Psikoloji Dergisi, 7(23), 14-18. http://www.turkpsikolojiyazilari.com/PDF/TPD/23/01.pdf

Doğan, U., \& Karakuş, Y. (2016). Lise öğrencilerinin sosyal ă̆ siteleri kullanımının yordayıcısı olarak çok boyutlu yalnızlık. Sakarya UniversityJournal of Education, 6(1), 57-71. https://doi.org/10.19126/suje.40198 
Frisby, C. (2010). Effects of Media Use on Athletes' Self-Perceptions, Mass Communication \& Society Division for consideration of presentation at the Association for Education in Journalism \& Mass Communication Annual Convention, Denver. https://www.researchgate.net/publication/305722497.

Greenwood, H. B. (2008). The relationship between the qualities of adolescents' online friendship and experience of loneliness. (Unpublished Doctoral Thesis), Alliant International University, San Diego.

Harter, S. (1999). Distinguished contributions in psychology. The construction of the self: A developmental perspective. New York, NY, US: Guilford Press. http://psycnet.apa.org/record/1999-02441-000.

Haugen, T., Säfvenbom, R., \& Ommundsen, Y. (2013). Sport Participation and Loneliness in Adolescents: The Mediating Role of Perceived Social Competence, Current psychology, 32, 203-216. https://doi.org/10.1007/s12144-013-9174-5

Heinrich, L. A., \& Gullone, E. (2006). The clinical significance of loneliness: A literature review. Clinical Psychology Review, 26, 695-718. https://doi.org/10.1016/j.cpr.2006.04.002

https://hootsuite.com (Retrieved 07-08-2018)

https://wearesocial.com (Retrieved 07-08-2018)

Huston, A. C. \& Ripke, M. N. (2006). Developmental contexts in middle childhood. New York: Cambridge University Press. https://doi.org/10.1017/CBO9780511499760

İlhan, T. (2012). Üniversite öğrencilerinde yalnızlık: cinsiyet rolleri ve bağlanma stillerinin yalnızlığı yordama güçleri, Educational Sciences: Theory \& Practice, 12(4), 2377-2396.

Jung, J. Y. (2012). Social media use and goals after the Great East Japan Earthquake, 17(8), First Monday. https://doi.org/10.5210/fm.v17i8.4071

Kaplan, A. M., \& Haenlein, M. (2010). Users of the world, unite! The challenges and opportunities of social media, Business Horizons, 53(1), 59-68. https://doi.org/10.1016/j.bushor.2009.09.003

Kelleci, M. (2008). The effects of internet use, cell phones and computer games on mental health of children and adolescents. TAF-Preventive Medicine Bulletin, 7(3), 253.

Kietzmann, J. H., Hermkens, K., McCarthy, I., \& Silvestre, B. S. (2011). Social media? Get serious! Understanding the functional building blocks of social media, 54(3), 241-251. https://doi.org/10.1016/ j.bushor.2011.01.005

Kraut, R., Patterson, M., Lundmark, V., Kiesler, S., Mukophadhyay, T., \& Scherlis, W. (1998). Internet paradox: A social technology that reduces social involvement and psychological well-being?. American Psychologist, 53, (9), 1017-1031. https://doi.org/10.1037/0003-066X.53.9.1017

Lauricella, A. R., Cingel, D. P., Blackwell, C., Wartella, E., \& Conway, A. (2014). The Mobile Generation: Youth and Adolescent Ownership and Use of New Media. Communication Research Reports, 31(4), $357-364$. https://doi.org/10.1080/08824096.2014.963221

Leung, L. (2002). “Loneliness, Self-Disclosure, and ICQ (“I Seek You”) Use,” CyberPsychology and Behavior, 5(3), 241-251. https://doi.org/10.1089/109493102760147240

Lou, L. L. (2009). Loneliness, Friendship, and Self-Esteem: First-Year College Students' Experience of Using Facebook. (Unpublished Doctoral Thesis), University at Albany, State University of New York, New York.

Martončik, M., \& Lokša, J. (2016). Do World of Warcraft (MMORPG) Players Experience Less Loneliness and Social Anxiety in Online World (Virtual Environment) Than in Real World (Offline)?. Computers in Human Behavior, 56, 127-134. https://doi.org/10.1016/j.chb.2015.11.035

Moody, E. J. (2001). Internet Use and Its Relationship to Loneliness. CyberPsychology and Behavior, 4(3), $393-401$. https://doi.org/10.1089/109493101300210303

Morahan-Martin, J., \& Schumacher, P. (2003). Loneliness and Social Uses of the Internet. Computers in HumanBehavior, 19(6), 659-671. https://doi.org/10.1016/S0747-5632(03)00040-2

Otrar, M. \& Argın, F. S. (2014). Öğrencilerin sosyal medyaya ilişkin tutumlarının kullanım alışkanlıkları bağlamında incelenmesi. Eğitim ve Öğretim Araştırmalarl Dergisi, http://www.jret.org/FileUpload/ks281142/File/01.otrar.pdf

Otrar, M. \& Argın, F. S. (2013). Öğrencilerin Sosyal Medyaya İlişkin Tutumlarını Belirlemeye Yönelik Bir Ölçek Geliştirme Çalışması. 7. Uluslararası Bilgisayar ve Öğretim Teknolojileri Sempozyumunda (ICITS) Erzurum, 
Atatürk Üniversitesi.

Ökte, A. (2014). Öğrencilerin zorbalık ĕgilimleri ile sosyal medyaya yönelik tutumları arasındaki ilişkinin incelenmesi (Sancaktepe örneği). Yeditepe Üniversitesi Sosyal Bilimler Enstitüsü, İstanbul.

Özgür, H. (2013). Öğretmen adaylarının sosyal ağ bağımlılı̆̆ı, etkileşim kaygısı ve yalnızlık düzeyi arasındaki ilişkinin incelenmesi. International Journal of Human Sciences, 10(2), 667-690.

Özsarı, İ., \& Karaduman, G. B. (2016). Eğitim fakültesi öğrencilerinin sosyal medya kullanımı ve yalnızlıklarının incelenmesi, Journal of Research in Education and Teaching, Cilt: 5, 41, 380-389. http://www.jret.org/FileUpload/ks281142/File/41.ismail_ozsari.pdf

Page, R. M., \& Zarco, E. P. (2001). Shyness, physical activity, and sports team participation among Philippine high school students. Child Study Journal, 31(3), 193-204. http://psycnet.apa.org/record/2002-00912-004

Page, R. M., \& Page, T. S. (1994). Adolescent loneliness linked to low physical fitness and physical inactivity. Wellness Perspectives, 10(3), 56-62.

Page, R. M., Frey, J., Talbert, R., \& Falk, C. (1992). Children's feelings of loneliness and social dissatisfaction: relationship to measures of physical fitness and activity. Journal of Teaching in Physical Education, 11, 211-219. https://doi.org/10.1123/jtpe.11.3.211

Pempek, T., Yermolayeva, A. Y., \& Calvert, L. S. (2009). College students' social networking experiences on Facebook. Journal of Applied Developmental Psychology, 30, 227-238. https://doi.org/10.1016/j.appdev.2008.12.010

Peplau, L. A., \& Perlman, D. (1982). Perspectives on loneliness: A sourcebook of current theory research and therapy. Wiley-Interscience, NY.

Poulsen, A. A., Ziviani, J. M., Johnson, H., \& Cuskelly, M. (2008). Loneliness and life satisfaction of boys with developmental coordination disorder: the impact of leisure participation and perceived freedom in leisure. Human Movement Science, 27, 325-343. https://doi.org/10.1016/j.humov.2008.02.004

Russell, D., Peplau, L. A., \& Cutrona, C. E. (1980). The Revised UCLA Loneliness Scale: Concurrent and Discriminant Validity Evidence. Journal of Personality and Social Psychology, 39, 472-480. https://doi.org/10.1037/0022-3514.39.3.472

Ryan, T., \& Xenos, S. (2011). Who Uses Facebook? An Investigation into the Relationship Between the Big Five,Shyness, Narcissism, Loneliness, and Facebook Usage. Computers in Human Behavior, 27(5), 1658-1664. https://doi.org/10.1016/j.chb.2011.02.004

Sanders, C. E., Field, T. M., Diego, M., \& Kaplan, M. (2000). The relationship of internet to depression and social 1solation among adolescents. Adolescence, 35(138), 237-242. https://www.ncbi.nlm.nih.gov/pubmed/11019768.

Schultz, N. R., Jr., \& Moore, D. (1986). The loneliness experience of college students: Sex differences. Personality and Social Psychology Bulletin, 12, 111-119. https://doi.org/10.1177/0146167286121011

Tiryaki, S. (2018). Yalnızlık ve benlik sunumu çerçevesinde sosyal medya kullanımı, The Journal of Social Science, $5,25,198-212$.

Usluel, Y. K., \& Mazman, S. G. (2009). Sosyal ağların benimsenmesi ölçeği. Educational Sciences \& Practice, 8(15). 137-157. http://dergipark.gov.tr/download/article-file/93174

Vural, Z. B., \& Bat, M. (2010). Yeni bir iletişim ortamı olarak sosyal medya: Ege üniversitesi iletişim fakültesine yönelik bir araştırma. Journal of Yasar University, 20(5), 3348-3382. https://journal.yasar.edu.tr/wp-content/uploads/2012/08/3_BVural_MBat.pdf

Whang, L. S-M., Lee, S., \& Chang, G. (2003). Internet over-users' psychological profiles: a behavior sampling analysis on internet addiction. CyberPsychology and Behavior, 6(2), 143-150. https://doi.org/10.1089/109493103321640338

Wirth, K. A. (2014). Understanding the Relationship Between Social Media, Fanship, and Behaviors in Collegiate Athletics, Thesis. Rochester Institute of Technology. Accessed from http://scholarworks.rit.edu/theses.

Woods, R. B. (2011). Social issues in sport (2 $2^{\text {nd }}$ ed.). Champaign, IL: Human Kinetics. 